\title{
Length correction for early-juvenile Brazilian herring Sardinella janeiro (Eigenmann, 1894) after preservation in formalin, ethanol and freezing
}

\author{
Joaquim N. S. Santos, Francisco G. Araújo and Débora S. Silva
}

This work aims to quantify the variation in total length and body mass for the early-juvenile Brazilian herring Sardinella janeiro and to determine total length and body mass correction equation to allow fresh measures to be calculated from preserved ones. Fishes were randomly assigned to one of five preservation methods (freezing at $-20^{\circ} \mathrm{C}, 2.5 \%$ and $5 \%$ formalin, $70 \%$ and $95 \%$ ethanol), and measured for total length (TL) and body mass (W) before preservation, and on days 5, 15, 30, and 60 after storage. Significant reductions in total length and body mass occurred during the first 5 days after preservation and continued to contract significantly at a lesser rate through 30 days in most methods. Exceptions were shown for body mass in freezing and 5\% formalin, where the greatest losses occurred after 30 days of preservation. The degree of shrinkage for total length and body mass was very much dependent on fish size, with smaller specimens shrinking more than larger ones. The fresh total length and body mass can be back-calculated using equations that describe the relationship between fresh and preserved individuals after 60 days storage for all methods except for body mass in freezing.

Este trabalho objetivou quantificar a variação do comprimento total e massa corporal para pós-larvas de Sardinella janeiro e determinar as equações de correção para o cálculo do comprimento total e da massa corporal a partir de espécimes preservados. Os peixes foram submetidos aleatoriamente a cinco métodos de preservação (congelamento $-20^{\circ} \mathrm{C}$, formalina $2,5 \%$ e $5 \%$, álcool 70\% e 95\%), e medidos o comprimento total (CT) e pesado a massa corporal (P) antes da preservação, e 5, 15, 30 e 60 dias após a preservação. Foram observadas perdas significantes no comprimento total e na massa corporal durante os cinco primeiro dias após a preservação, prosseguindo em menor intensidade até o $30^{\circ}$ dia na maioria dos métodos. Exceções foram observadas para a massa corporal em congelamento e formalina 5\%, com perdas ocorrendo mesmo depois de 30 dias de preservação. O grau de perdas para comprimento total e massa corporal foi significativamente dependente do tamanho dos peixes, com os menores indivíduos sofrendo as maiores perdas. O comprimento total e massa corporal de indivíduos frescos podem ser retro-calculados usando equações que descrevem a relação entre indivíduos frescos e após 60 dias de preservação para a maioria dos métodos, exceto para a massa corporal em congelamento.

Key words: Shrinkage, Storage, Back-calculation, Initial length, Size conversion, Clupeidae.

\section{Introduction}

Storage in formalin, ethanol or by freezing are frequently used to preserve fish for scientific purposes, and generally result in shrinkage of fish body mass and length (Buchheister \& Wilson, 2005; Fey \& Hare, 2005). The preserved individuals can be used to estimate population parameters such as size structure, growth rate, condition factor and length-body mass relationship, with these parameters being indicators of well being state of populations. Since these parameters are assigned from preserved species, such measures could not be reflecting the real species conditions, and the results of the subsequent analyses being significantly biased (Fey, 1999; Porter et al., 2001; Santos et al., 2005). With the purpose of correcting such variation in specimens length and body mass which usually occur with the preservation, several workers have proposed a correction factor to estimate initial length and body mass by using appropriate equations (e.g. Buchheister \& Wilson, 2005; Fey \& Hare, 2005; Fey, 1999, 2002; Porter et al., 2001).

The time of preservation, species age and the preservation method are the most important factors affecting shrinkage, generally losses of length and body mass. The highest losses occur in the first days of preservation, in the youngest

Universidade Federal Rural do Rio de Janeiro, Laboratório de Ecologia de Peixes, Km 47 Antiga Rodovia Rio-SP, 23.851-970 Seropédica, RJ, Brazil.jnssantos@yahoo.com.br(JNSS),gerson@ufrj.br(FGA),debora_desouza@yahoo.com.br (DSS) 
individuals (Fey, 1999, 2002; Radtke, 1989) and in specimens preserved in ethanol at concentrations near to absolute (Hjörleifsson \& Klein-MacPhee, 1992). Loss in length can vary between $5 \%$ and $40 \%$ for larvae preserved in $70 \%$ and 95\% ethanol, respectively (Fowler \& Smith, 1983; Jennings, 1991; Radtke, 1989). The amount of shrinkage generally depends on the osmolarity of the preservative (Tucker \& Chester, 1984), thus seawater formaldehyde solution will lead to a greater shrinkage than freshwater formaldehyde. Morkert \& Bergstedt (1990) reported that length of larvae usually decrease about $4.3 \%$ after preservation in $10 \%$ formalin, varying according to concentration, salinity and the particular species. Despite of such effects, preservation in formalin is the most common for the ichthyoplankton (Smith \& Richardson, 1977). However, because of decalcification of skeletal structure in formalin and ethanol that acts as a weakly acid, the freezing is the most recommended method for the preservation of larvae for age estimation from daily rings in otoliths (Santos et al., 2005; Brothers, 1987).

Hjörleifsson \& Klein-MacPhee (1992) recommend that if there is previous knowledge about a given species shrinkage variability, it is important to choose the preservation method. This procedure minimizes possible errors or even can increases the accuracy of the results, since such losses are speciesspecific. The most important use of shrinkage studies is to predict live size and body mass. The type of preservative used depends on the purpose of the study as well as the precision with which fresh length and body mass can be estimated from preserved length and body mass. Due to preservation effect on fish size, measurements may need to be adjusted for changes in length and mass using appropriate equation, particularly when combining different data sets. The present work aims to quantify the variation in length and body mass for the Brazilian herring Sardinella janeiro (Eigenmann, 1894) preserved in freezing, formalin and ethanol, and to indicate length and body mass correction equations to allow live measures to be calculated from preserved ones.

\section{Material and Methods}

Data on fish length and body mass were obtained from samples collected in sandy beaches in Rio de Janeiro, Southeastern Brazil, from March to April 2006. Early-juvenile $S$. janeiro were collected using a small-mesh beach seine (12 x $2 \mathrm{~m} ; 4 \mathrm{~mm}$ meshed cod-end liner). Immediately after to be collected, fishes were anesthetized by addition of a small amount of benzocaine and placed in plastic bags containing local seawater and ice to keep temperature low during transportation. Fresh total length (TL) was measured to the nearest $0.01 \mathrm{~mm}$ with a caliper and fresh whole wet body mass (W) of blotted-dry individuals was measured to the nearest $0.001 \mathrm{~g}$ using an electronic balance. Samples were divided in 5 similar size groups, corresponding to each preservation method, ranging from 15.07 to $28.11 \mathrm{~mm}$ TL and 0.021 to 0.092 g. Each group of sample was stored by freezing at $-20^{\circ} \mathrm{C}$, in $2.5 \%$ formalin (buffered with $2 \%$ sodium borate mixed with seawater $32-35, \mathrm{pH} 7.6$ ), $5 \%$ formalin (buffered with $4 \%$ sodium borate mixed with seawater 32-35, $\mathrm{pH} 8.1$ ), $70 \%$ ethanol and $95 \%$ ethanol.

Fishes were measured and weighed five times: before preservation, then at 5, 15,30 and 60 days after preservation. For fishes storage in freezing, the body mass was measured only after thawing to avoid influence of possible ice incorporated in the tissues that could overestimate the species body mass. The percentage change in length or body mass was calculated as: 100 (fresh size - preserved size) (fresh size) $)^{-1}$ or 100 (fresh body mass - preserved body mass) (fresh body mass $)^{-1}$. ANOVA was used to compare individual's total length among the five groups before preservation and to compare shrinkage among the methods after 60 days preservation. A $t$-test for $H_{\mathrm{o}}$ : slope $=0(\mathrm{p}<0.05)$ was used to verify if there is difference in shrinkage throughout fish size. Equations describing the shrinkage in body mass and length are given based on least- square regression relationships between fresh and preserved body mass and length after 60 days. These equations were used for conversion between preserved and fresh body mass and length. To determine if a single correction factor is appropriate for a calculation of fresh length or body mass, a $t$-test ( $t$-test analysis for $H_{\mathrm{o}}$ : slope $=1$, $\mathrm{p}>0.05$ ) was performed. If the $y$-intercept was significantly different from zero $\left(t\right.$-test analysis for $H_{\mathrm{o}}: y$-intercept $=0, \mathrm{p}<$ $0.05)$ it can be used as a single correction factor.

\section{Results}

The means of the TL of $S$. janeiro were similar $(\mathrm{F}=0.37$; d.f $=4 ; p=0.83$ ) among the five groups on day zero, indicating that the early-juvenile had been randomly sorted. The examined preservation methods influenced significantly on length and body mass of $S$. janeiro (ANOVA, $\mathrm{p}<0.001$ ). Furthermore, losses in total length and body mass after 60 days showed significant differences among the preservation methods (Tukey HSD, $\mathrm{p}<0.001$ ).

Shrinkage with freezing. The decrease in body length was initially rapid, and the majority of the length reduction occurred in the first 5 days (means $=1.31 \% ; \mathrm{SE}=0.16$ ). After 60 days the mean decrease in total length was $1.91 \% \pm 0.16 \mathrm{SE}$ (Fig. 1). The highest reductions in body mass were seen within the first 30 days $(7.13 \% \pm 0.54 \mathrm{SE})$. The means body mass loss after 60 was $7.18 \% \pm 0.53$ SE (Fig. 2).

Shrinkage with $2.5 \%$ formalin. The decrease in body length was highest in the first 5 days $(1.78 \% \pm 0.14 \mathrm{SE})$, and length after 60 days of preservation was $3.81 \% \pm 0.12 \mathrm{SE}$ (Fig. 1). The highest reduction in body mass occured during the first 5 days of preservation $(2.71 \% \pm 0.44 \mathrm{SE})$ reaching $6.47 \% \pm 0.38$ SE after 30 days and $6.56 \% \pm 0.43 \mathrm{SE}$ after 60 days (Fig. 2).

Shrinkage with $5 \%$ formalin. The majority of the length reduction occurred during the first 5 days $(1.96 \% \pm 0.20 \mathrm{SE})$. After 60 days of preservation the mean shrinkage was $4.83 \%$ 
$\pm 0.17 \mathrm{SE}$ (Fig. 1). Body mass reduction was higher during the first 30 days of preservation $(6.90 \% \pm 0.34 \mathrm{SE})$ (Fig. 2). After 60 days the body mass loss reached $7.52 \% \pm 0.36 \mathrm{SE}$.

Shrinkage with $\mathbf{7 0} \%$ ethanol. Reduction in body length was higher in the first 5 days of preservation $(4.64 \% \pm 0.21 \mathrm{SE})$, and after 60 days was $8.68 \% \pm 0.18 \mathrm{SE}$ (Fig. 1). The highest body mass reduction occurred during the first 5 days $(7.53 \%$ $\pm 0.39 \mathrm{SE}$ ) (Fig. 2). Mean body mass loss after 60 was $10.60 \%$ $\pm 0.44 \mathrm{SE}$.

Shrinkage with $\mathbf{9 5 \%}$ ethanol. The decrease in body length was initially rapid, and the majority of length reduction occurred in the first 5 days $(9.23 \% \pm 0.26 \mathrm{SE})$. After 60 days of preservation loss in body length was $13.49 \% \pm 0.23 \mathrm{SE}$ (Fig. $1)$. The highest body mass reduction occurred mainly in the first 5 days of preservation $(8.74 \% \pm 0.35 \mathrm{SE})$ (Fig. 2). Mean loss after 60 days was $15.29 \% \pm 0.34 \mathrm{SE}$.

Losses in total length and body mass varied according to total length. The percentage deviation decreased with increasing body size; the smaller the individuals the higher losses were recorded for all preservation methods ( $t$-test, $H_{\mathrm{o}}$ : slope $=0, p<0.001)($ Fig. 3-4). The reduction in total length after 60 days of preservation, in decreasing order, was for fishes preserved in $95 \%$ ethanol, $70 \%$ ethanol, $5 \%$ formalin, $2.5 \%$ formalin and freezing (Tukey HSD, $\mathrm{p}<0.005$ ). Loss of body mass was higher in specimens preserved in $95 \%$ ethanol, followed, in decreasing order, by $70 \%$ ethanol, $5 \%$ formalin, freezing and $2.5 \%$ formalin. Body mass loss did not differed significantly between freezing, $2.5 \%$ and $5 \%$ formalin (Tukey HSD, $\mathrm{p}=0.40$ ).

The relationships between fresh and preserved total length and body mass were described by a linear regression for all 5 preservatives (Table 1). All $y$-intercepts were highly significantly different from zero $\left(H_{0}: y\right.$-intercept $=0 ; t$-test of

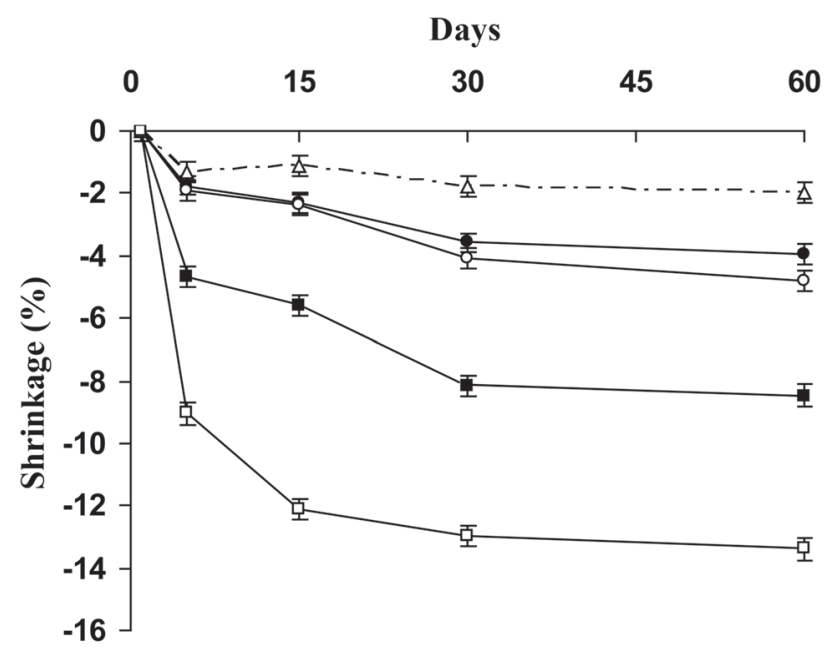

Fig. 1. Mean percentage shrinkage of total length for earlyjuvenile of Sardinella janeiro during storage in freezing (open triangle), $2.5 \%$ formalin (full circle), $5 \%$ formalin (open circle), $70 \%$ ethanol (full square) and $95 \%$ ethanol (open square).

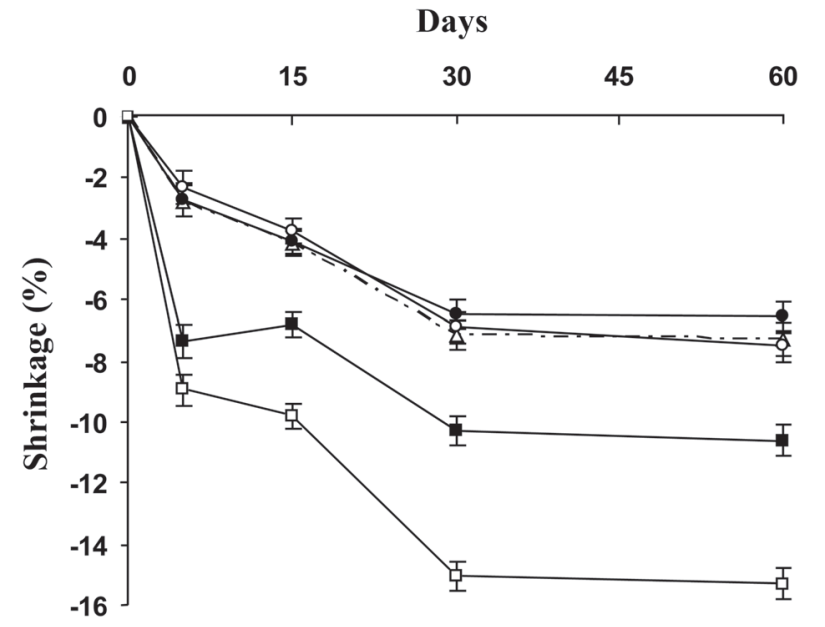

Fig. 2. Mean percentage shrinkage of body mass for earlyjuvenile of Sardinella janeiro during storage in freezing (open triangle), $2.5 \%$ formalin (full circle), $5 \%$ formalin (open circle), $70 \%$ ethanol (full square) and $95 \%$ ethanol (open square).
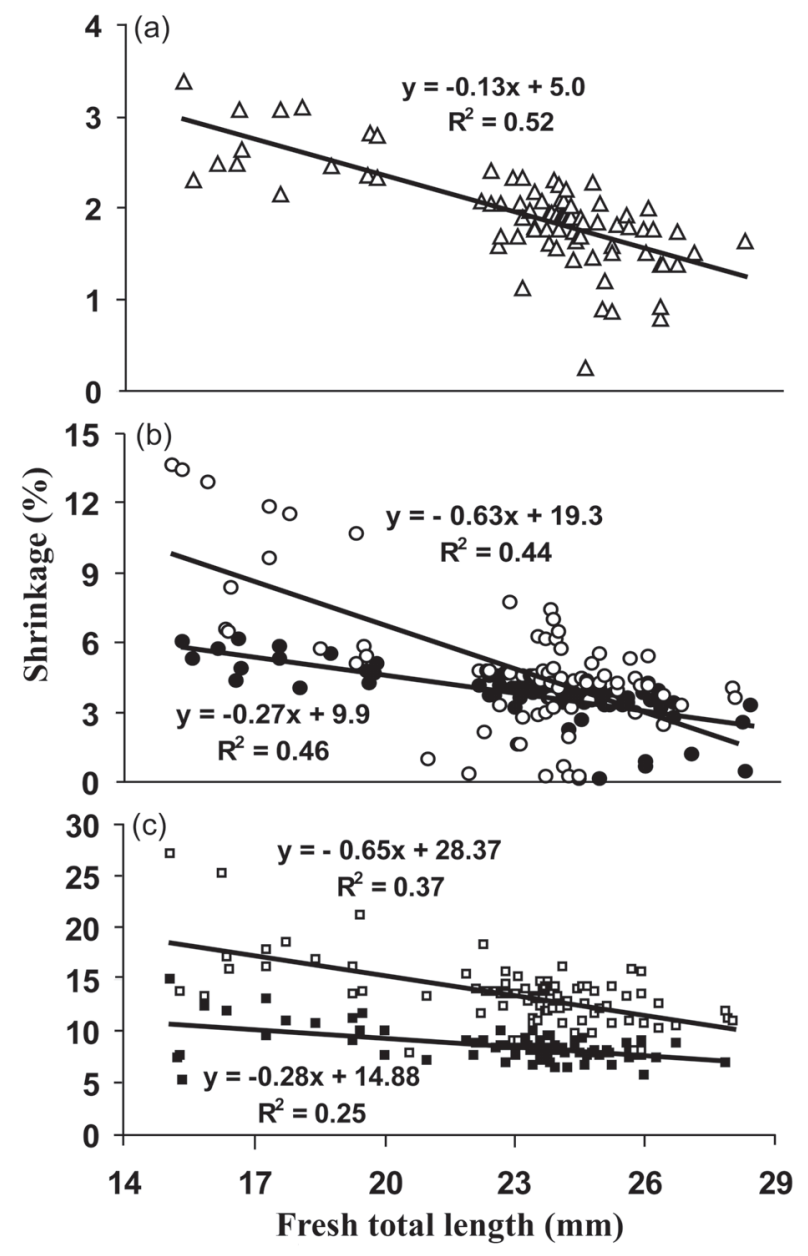

Fig. 3. The relationship between fresh total length and relative (\%) shrinkage in total length after 60 days of preservation for early-juvenile of Sardinella janeiro. (a) Freezing (open triangle), (b) $2.5 \%$ formalin (full circle), $5 \%$ formalin (open circle), (c) $70 \%$ ethanol (full square) and $95 \%$ ethanol (open square). 




Fig. 4. The relationship between fresh total length and relative (\%) shrinkage in body mass after 60 days of preservation for early-juvenile of Sardinella janeiro. (a) Freezing (open triangle), (b) $2.5 \%$ formalin (full circle), $5 \%$ formalin (open circle), (c) $70 \%$ ethanol (full square) and $95 \%$ ethanol (open square). regression intercept, $\mathrm{p}<0.001$ ) with exception of the freezing method for body mass $(p=0.053)$. The slopes of the regressions of preserved total length at 60 days were not significantly different from one $\left(H_{\mathrm{o}}\right.$ : slope $=1 ; t$-test of slope, $\mathrm{p}>0.05$ ) in $70 \%$ and $95 \%$ ethanol and of body mass in freezing and $2.5 \%$ and $5 \%$ formalin. Significant differences from one in slopes $\left(H_{0}:\right.$ slope $=1 ; t$-test of slope, $\left.\mathrm{p}<0.036\right)$ were detected for preserved length at 60 days in freezing, and $2.5 \%$ and $5 \%$ formalin, and of body mass in $70 \%$ and $95 \%$ ethanol. Therefore, a single correction $y$-intercept $\left(y\right.$-intercept ${ }^{1} 0$ and slope $=1$ ) can be used for conversion between preserved and fresh length in $70 \%$ and $95 \%$ ethanol and between preserved and fresh body mass in $2.5 \%$ and $5 \%$ formalin. The equation can be used for length correction for preserved length at 60 days in freezing, and $2.5 \%$ and $5 \%$ formalin, and of body mass in $70 \%$ and $95 \%$ ethanol. Correction factor or equations are not appropriate for correcting body mass storage in freezing.

\section{Discussion}

Shrinkage of early-juvenile Brazilian herring S. janeiro varied among the preservation methods. The greatest shrinkage mean value of preserved length $(13.49 \% \pm 0.23 \mathrm{SE})$ and body mass $(15.29 \% \pm 0.34 \mathrm{SE})$ was in ethanol (mainly $95 \%$ ethanol) when compared with formalin or storage in freezing. Shrinkage varies because of the differing ionic strengths of these solutions (Parker, 1963; Hay, 1982; Tucker $\&$ Chester, 1984). Some studies report a smaller shrinkage in ethanol (e.g. Theilacker, 1980; Hjörleifsson \& Klein-MacPhee, 1992; Porter et al., 2001) when compared with formalin, but the majority has found a higher shrinkage in ethanol (e.g. Fowler \& Smith, 1983; Kruse \& Dalley, 1990; Fox, 1996; Kristoffersen \& Salvanes, 1998; Moku et al., 2004; Thorstad et al., 2007). Ethanol has been found to distort larvae and cause greater variability in shrinkage estimates compared with formaldehyde preservation (Fox, 1996). Different processes cause body mass loss in formaldehyde and ethanol, respectively. Both formaldehyde and ethanol extract water from tissue. Formaldehyde also dissolves glycogen, glucose, some phospholipids and inorganic salts (Steedman, 1976),

Table 1. Least-squares linear regression equations for shrinkage of Sardinella janeiro for different preservation methods and $t$-test statistics $\left(H_{\mathrm{o}}\right.$ : slope $=1$ and $y$-intercept $\left.=0\right)$. The ranges of data are based on preserved measurements. $\mathrm{TL}_{\mathrm{p}}=$ preserved total length; $\mathrm{W}_{\mathrm{p}}=$ preserved body mass. $\mathrm{y}$-inter $=y$-intercept. $\mathrm{ns}=$ nonsignificant differences $(\mathrm{p}>0.05)$.

\begin{tabular}{|c|c|c|c|c|c|c|c|c|}
\hline $\begin{array}{l}\text { Preservation } \\
\text { Method }\end{array}$ & Regression equation & $\mathrm{n}$ & $\mathrm{R}^{2}$ & $\begin{array}{c}\mathrm{TL}_{\mathrm{p}} \text { and } \mathrm{W}_{\mathrm{p}} \\
\text { ranges }\end{array}$ & $\begin{array}{c}\text { t-test } \\
\text { Slope }=1\end{array}$ & $\mathrm{p}$ & $\begin{array}{c}\text { t-test } \\
\mathrm{y} \text {-inter }=0\end{array}$ & $\mathrm{p}$ \\
\hline \multirow[t]{2}{*}{ Freezing $-20^{\circ} \mathrm{C}$} & $\mathrm{TL}_{\mathrm{fresh}}=0.992 \mathrm{TL}_{\mathrm{p}}+0.6152$ & 82 & 0.999 & $14.32-27.01 \mathrm{~mm}$ & 2.26 & 0.035 & 8.04 & $<0.001$ \\
\hline & $\mathrm{W}_{\text {fresh }}=1.0263 \mathrm{~W}_{\mathrm{p}}+0.0023$ & & 0.956 & $0.018-0.082 \mathrm{~g}$ & 1.12 & ns & 1.96 & ns \\
\hline \multirow[t]{2}{*}{ Formalin $2.5 \%$} & $\mathrm{TL}_{\mathrm{fresh}}=0.9797 \mathrm{~L}_{\mathrm{p}}+1.2928$ & 85 & 0.994 & $14.05-26.94 \mathrm{~mm}$ & 2.36 & 0.019 & 6.76 & $<0.001$ \\
\hline & $\mathrm{W}_{\text {fresh }}=1.005 \mathrm{~W}_{\mathrm{p}}+0.0027$ & & 0.985 & $0.017-0.085 \mathrm{~g}$ & 0.37 & ns & 4.20 & $<0.001$ \\
\hline \multirow[t]{2}{*}{ Formalin 5\% } & $\mathrm{TL}_{\text {fresh }}=0.9226 \mathrm{~L}_{\mathrm{p}}+2.7632$ & 84 & 0.982 & $14.22-26.67 \mathrm{~mm}$ & 5.27 & $<0.001$ & 8.89 & $<0.001$ \\
\hline & $\mathrm{W}_{\text {fresh }}=1.0003 \mathrm{~W}_{\mathrm{p}}+0.0034$ & & 0.960 & $0.016-0.087 \mathrm{~g}$ & 0.01 & ns & 3.24 & $<0.002$ \\
\hline \multirow[t]{2}{*}{ Ethanol $70 \%$} & $\mathrm{TL}_{\text {fresh }}=1.0024 \mathrm{~L}_{\mathrm{p}}+1.9031$ & 83 & 0.992 & $13.74-26.01 \mathrm{~mm}$ & 0.24 & ns & 6.35 & $<0.001$ \\
\hline & $\mathrm{W}_{\text {fresh }}=1.0425 \mathrm{~W}_{\mathrm{p}}+0.0025$ & & 0.991 & $0.013-0.078 \mathrm{~g}$ & 4.03 & $<0.001$ & 5.08 & $<0.001$ \\
\hline \multirow[t]{2}{*}{ Ethanol 95\% } & $\mathrm{TL}_{\text {fresh }}=0.9812 \mathrm{~L}_{\mathrm{p}}+3.4276$ & 85 & 0.970 & $13.02-25.05 \mathrm{~mm}$ & 0.99 & ns & 9.03 & $<0.001$ \\
\hline & $\mathrm{W}_{\text {fresh }}=1.1281 \mathrm{~W}_{\mathrm{p}}+0.0018$ & & 0.983 & $0.012-0.078 \mathrm{~g}$ & 8.98 & $<0.001$ & 2.67 & $<0.009$ \\
\hline
\end{tabular}


while ethanol extracts much of the lipids present in specimens (Glauert, 1974). Thus, extraction of the lipids which are abundant in clupeids (e.g. S. janeiro) may account for the largest reduction in body mass.

The higher shrinkage in ethanol may partly be caused by a genuine shrinkage, and partly by higher rigidity of the fish after preservation compared with fish preserved on formaldehyde, making it harder to flatten fish (Kristoffersen $\&$ Salvanes, 1998). Thus, measures of the length of ethanol preserved fish may be underestimated when compared with formaldehyde preserved fishes. Therefore, the greatest losses of weight and length in ethanol in the present study may be caused by water and organic loss as well as by rigidity after preservation, which influences loss in body mass and length, respectively, when compared with specimens preserved in formalin and freezing.

In all preservation methods loss in length and body mass varied according to the time of preservation. Shrinkage was greatest soon after preservation, that is, mean shrinkage values in the first 5 days significantly exceeded zero $(\mathrm{p}<0.001)$ in most methods for both length and body mass. The only exception was for body mass in freezing and 5\% formalin, where the greatest losses occurred after 30 days of preservation. According to Fey \& Hare (2005) larvae of Brevoortia tyrannus (Latrobe, 1802) preserved in 95\% ethanol shrinkage stabilizes within a few days. Larvae of Cololabis saira (Brevoort, 1856) preserved in 5\% formalin have shown that the amounted of shrinkage stabilizes after one month (Oozeki et al., 1991). In general most studies agree that the length shrinkage stabilizes between a few days to one month (Fey, 1999; Fox, 1996; Smith \& Walker, 2003; Moku et al., 2004).

As the fish size increased, a decrease in shrinkage was observed in this study. This situation have been widely reported in the literature, such as for the clupeids Clupea harengus Linnaeus (Hay, 1982; Fey, 2002), B. tyrannus (Fey $\&$ Hare, 2005) and Sprattus sprattus Linnaeus (Fey, 1999) and other fish species such as Pleuronectes americanus (Walbaum, 1792) (Hjörleifsson \& Klein-MacPhee, 1992), Stizostedion vitreum (Mitchill, 1818) (Johnson \& Mathias, 1993), Merluccius bilinearis (Mitchill, 1814) (Fowler \& Smith, 1983), Gadus morhua Linnaeus (Radtke \& Waiwood, 1980; Radtke, 1989), and Enchelyopus cimbrius Linnaeus (Fey, 1999). This phenomenon is probably closely related to the decrease in the water content of larval tissues as length increases (Ehrlich, 1974). Additionally, it could be also likely a result of decreasing surface area in relation to volume ratios as reported by Hay (1984).

The size range is important to detect trends in shrinkage between small and large fishes. In this work, TL range from 15 to $28 \mathrm{~mm}$. This seems to be sufficient to detect changes in shrinkage between small and large fishes in all preservation methods. Thorstad et al. (2007) did not find correlation between body mass or length and mean shrinkage after preservation in ethanol, probably because of the more limited size range in juvenile European minnow Phoxinus phoxinus Linnaeus.
The length and body mass of preserved $S$. janeiro can be converted to fresh length and body mass through conversion equations. For this, a single correction may be applied to estimate fresh length and body mass from 60 days preserved specimens in $70 \%$ and $95 \%$ ethanol for length, and in $2.5 \%$ and $5 \%$ formalin for body mass. These findings are in accordance to Fey \& Hare (2005) and Buchheister \& Wilson (2005), who reported a single correction for length of $B$. tyrannus, Theragra chalcogramma (Pallas, 1814), Mallotus villosus (Müller, 1776) and Thaleichthys pacificus (Richardson, 1836) preserved in $95 \%$ ethanol. However, single correction can be applied only in situations with $b$ (slope) $=1$ and a ( $y$-intercept) different from zero.

The complete equations for conversion between fresh and preserved individuals are valid when $b^{1} 1$ and the $y$-intercept ${ }^{1}$ zero. This was the case for length in freezing, 2.5\% and 5\% formalin, and for body mass in $70 \%$ and $95 \%$ ethanol method. Additionally, linear regression provided good fits to plots of fresh lengths against stored lengths after stabilization. Hjörleifsson \& Klein-MacPhee (1992), Fox (1996), Morkert \& Bergstedt (1990) reported models to predict fresh lengths from preserved specimens of $P$. americanus, $C$. harengus and Petromyzon marinus Linnaeus. Furthermore, Smity \& Walker (2003) proposed equations for both length and body mass conversion of Cyprinus carpio Linnaeus preserved in $70 \%$ and $95 \%$ ethanol. On the other hand, correction equation is not appropriate for $S$. janeiro body mass storage in freezing. These findings were also reported by Hjörleifsson \& KleinMacPhee (1992) for standard length of winter flounder $P$. americanus larvae frozen preserved. Predicting fresh body mass from frozen samples is impossible when high variability in shrinkage occurs.

\section{Acknowledgments}

We thank Benjamin Carvalho Teixeira Pinto for helping in fieldwork. This work was financially supported by CNPq Conselho Nacional de Desenvolvimento Científico e Tecnológico (Proc. 522317/96-0) and FAPERJ - Fundação Carlos Chagas Filho de Amparo à Pesquisa do estado do Rio de Janeiro (Proc. E-26/170.258/2001).

\section{Literature Cited}

Brothers, E. B. 1987. Methodological approaches to the examination of otoliths in aging studies. Pp. 319-330. In: Summerfelt R. C. $\&$ G. E. Hall (Eds.). Age and growth of fish. Iowa State University Press: Ames,

Buchheister, A. \& M. T. Wilson. 2005. Shrinkage correction and length conversion equations for Theragra chalcogramma, Mallotus villosus and Thaleichthys pacificus. Journal of Fish Biology, 67: 541-548.

Ehrlich, K. F. 1974. Chemical changes during growth and starvation of herring larvae. Pp. 301-324. In: Blaxter, J. H. S. (Ed.). The Early Life History of Fish. Springer-Verlag: New York,

Fey, D. P. \& J. A. Hare. 2005. Length correction for larval and earlyjuvenile Atlantic menhaden (Brevoortia tyrannus) after 
preservation in alcohol. Fishery Bulletin, 103: 725-727.

Fey, D. P. 2002. Length correction of larval and early-juvenile herring (Clupea harengus) and smelt (Osmerus eperlanus) after preservation in formalin and alcohol. Bulletin of the Sea Fisheries Institute, 155: 47-51.

Fey, D. P. 1999. Effects of preservation technique on the length of larval fish: methods of correcting estimates and their implication for studying growth rates. Archive of Fishery and Marine Research, 47: 17-29.

Fox, C. J. 1996. Length changes in herring (Clupea harengus) larvae: effects of capture and storage in formaldehyde and alcohol. Journal of Plankton Research, 18: 483-493.

Fowler, G. M. \& S. J. Smith. 1983. Length changes in silver hake (Merluccius bilinearis) larvae: effects of formalin, ethanol, and freezing. Canadian Journal of Fisheries and Aquatic Sciences, 40: 866-870.

Glauert, A. M. 1974. Practical methods in electron microscopy. Fixation, dehydration and embedding of biological specimens. Vol. 3: part I. Amsterdam, North-Holland Publishing Company. $271 \mathrm{p}$.

Hay, D. E. 1982. Fixation shrinkage of herring larvae: Effects of salinity, formalin concentration, and other factors. Canadian Journal of Fisheries and Aquatic Sciences, 39: 1138-1143.

Hay, D. E. 1984. Weight loss and change of condition factor during fixation of Pacific Herring, Clupea harengus pallasi, eggs and larvae. Journal of Fish Biology, 25: 421-433.

Hjörleifsson, E. \& G. Klein-Macphee. 1992. Estimation of live standard length of Winter Flounder Pleuronectes americanus larvae from formalin-preserved, ethanol-preserved and frozen specimens. Marine Ecology Progress Series, 82: 13-19.

Jennings, S. 1991. The effects of capture, net retention and preservation upon lengths of larval and juvenile bass, Dicentrarchus labrax. Journal of Fish Biology, 38: 349-357.

Kristoffersen, J. B. \& A. G. V. Salvanes. 1998. Effects of formaldehyde and ethanol preservation on body and otoliths of Maurolicus muelleri and Benthosema glaciale. Sarsia, 83: 95-102.

Kruse, G. H. \& E. L. Dalley. 1990. Length changes in capelin, Mallotus villosus, larvae due to preservation in formalin and anhydrous alcohol. Journal of Fish Biology, 36: 619-621.

Moku, M., K. Mori \& Y. Watanabe. 2004. Shrinkage in the Body Length of Myctophid Fish (Diaphus Slender-Type spp.) Larvae with Various Preservatives. Copeia, 2004(3): 647-651.

Morkert, S. B. \& R. A. Bergstedt. 1990. Shrinkage of sea lamprey larvae preserved in formalin. North American Journal Fisheries Management, 10: 484-486.

Oozeki, Y., Y. Watanabe, Y. Kuji \& S. Takahashi. 1991. Effects of various preservatives on the body length of saury larvae. Bulletin Nature Fisheries Research Institute, 53: 15-21.

Parker, R. R. 1963. Effects of formalin on length and weight of fishes. Journal of Fisheries Research Board Canada, 20: 1441-1455.

Porter, S. M., A. L. Brown \& K. M. Bailey. 2001. Estimating live standard length of net-caught walleye pollock (Theragra chalcogramma) larvae using measurements in addition to standard length. Fishery Bulletin, 99: 691-696.

Radtke, R. L. 1989. Larval fish age, growth, and body shrinkage: information available from otoliths. Canadian Journal of Fisheries and Aquatic Sciences, 46: 1884-894.

Radtke, R. L. \& Waiwood K. G. 1980. Otolith formation and body shrinkage due to fixation in larval cod (Gadus morhua). Canadian Technical Report of Fisheries and Aquatic Sciences, 929: 1-10.
Santos, J. N. S., M. A. Silva, R. M. Vasconcellos \& F. G. Araújo. 2005. Effect of the conservation period of the specimens on the microstructure quality of sagittae otoliths in Anchoa tricolor (Agassiz) (Clupeiformes, Engraulidae). Revista Brasileira de Zoologia, 22: 949-952.

Smith, P. E. \& S. L. Richardson. 1977. Standard techniques for pelagic fish egg and larva surveys. FAO Fisheries Technical Paper, 175: 1-100.

Smith, B. B. \& Walker K. F. 2003. Shrinkage of $0+$ carp (Cyprinus carpio) after preservation in ethanol. Marine and Freshwater Research, 54: 113-116.

Steedman, H. F. 1976. General and applied data on formaldehyde fixation and preservation of marine zooplankton. Pp. 103-154. In: Zooplankton Fixation and Preservation. (UNESCO Press: Paris). Monographic Oceanography Methods, 4

Theilacker, G. H. 1980. Changes in body measurements of larval northern anchovy, Engraulis mordax, and other fishes due to handling and preservation. Fishery Bulletin, 78: 685-692.

Thorstad, E. B., A. G. Finstadand \& A. J. Jensen. 2007. To what extent does ethanol and freezing preservation cause shrinkage of juvenile Atlantic salmon and European minnow? Fisheries Management and Ecology, 14: 295-308.

Tucker, J. W. \& A. J. Chester. 1984. Effects of salinity, formalin concentration and buffer on quality of preservation of southern flounder (Paralichthys lethostigma) larvae. Copeia, 1984(5): 981988.

Accepted October 2008

Published March 31, 2009 